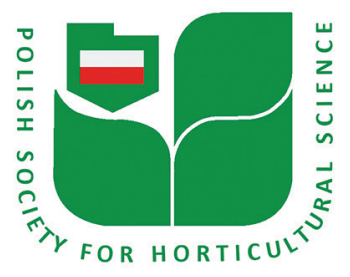

Folia Hort. 33(2) (2021): 293-308

\title{
Biochemical composition and shape-dimensional traits of rosehip genotypes
}

\author{
Bünyamin Demir ${ }^{1, *}$, Bahadır Sayıncı ${ }^{1}$,Mehmet Yaman', Ahmet Sümbül's, \\ Ercan Yıldız', Orhan Karakaya ${ }^{4}$, Günseli Bobuş Alkaya ${ }^{5}$, Sezai Ercişli ${ }^{6}$
}

\footnotetext{
${ }^{1}$ Department of Mechanical Engineering, Faculty of Engineering, Mersin University, 33340, Yenişehir, Mersin, Turkey ${ }^{2}$ Department of Horticulture, Faculty of Agriculture, Erciyes University, 38280, Talas, Kayseri, Turkey ${ }^{3}$ Department of Plant and Animal Production, Suşehri Timur Karabal Vocational School, Sivas Cumhuriyet University, 58600, Suşehri, Sivas, Turkey

${ }^{4}$ Department of Horticulture, Faculty of Agriculture, Ordu University, 52200, Altınordu, Ordu, Turkey ${ }^{5}$ Department of Food Engineering, Institute of Science, Mersin University, 33340, Yenişehir, Mersin, Turkey ${ }^{6}$ Department of Horticulture, Faculty of Agriculture, Atatürk University, 25240, Yakutiye, Erzurum, Turkey
}

\begin{abstract}
In the present study, the biochemical composition and shape and dimensional traits of 25 rosehip (Rosa canina) genotypes were investigated. The shape and dimensional traits were determined by image processing technique. Seed-propagated rosehip genotypes belonging to $R$. canina were collected from the natural flora of Mesudiye (Ordu) and Talas (Kayseri) districts. Antioxidant activity $\left(39.510-72.673 \mathrm{mmol} \cdot \mathrm{kg}^{-1}\right)$, total flavonoids $(287.80-1,686.20 \mathrm{mg}$ quercetin equivalent $\left.(\mathrm{QE}) \cdot \mathrm{kg}^{-1}\right)$ and total phenolics $\left(38,519.40-79,080.60 \mathrm{mg}\right.$ gallic acid equivalent $\left.\cdot \mathrm{kg}^{-1}\right)$ of the genotypes exhibited large variations. Width $(12.2 \mathrm{~mm})$ and thickness $(12.5 \mathrm{~mm})$ of fruits averages were found to be close to each other. The genotypes exhibited fruit lengths between $12.0 \mathrm{~mm}$ and $29.5 \mathrm{~mm}$. Average projected area at horizontal orientation $\left(179.7 \mathrm{~mm}^{2}\right) \mathrm{was}$ greater than the projected area at vertical orientation $\left(120.4 \mathrm{~mm}^{2}\right)$. Sphericity average was calculated as $71.4 \%$. According to principal component (PC) analysis, the most important dimensional traits discriminating genotypes from each other were identified as surface area, geometric mean diameter and volume. In terms of shape attributes, distinctive differences were observed in sphericity, circularity, elongation and surface closure rates (SCR) of the genotypes. According to elliptic Fourier analysis (EFA), genotypes look like a sphere. In terms of shape, there were long, spherical, flat bottomed, pointed bottomed and asymmetric-looking genotypes indicating how environment and genotype affect the fruit shape. The greatest shape variation was transverse contraction and expansion. According to the clustering analysis for shape attributes, rosehip genotypes were classified into six groups. Dendrogram, scatter plots of linear discriminant analysis and paired comparison test results put forth the shape differences of the genotype successfully.
\end{abstract}

Keywords: biochemical composition, elliptic Fourier analysis, physical characteristics, rosehip, sphericity

\section{INTRODUCTION}

There are about 100 species in Rosa and 30 of them have a natural spread in Anatolia (Kutbay and Kilinc, 1996). All Rosa species show great environmental plasticity and are naturally grown in diverse climate, soil and altitude conditions in several countries of Caucasus, Western and Central Asia, Europe and Northwestern

*Corresponding author.

e-mail: bd@mersin.edu.tr (Bünyamin Demir). 
Africa between $30 \mathrm{~m}$ and $1,700 \mathrm{~m}$, in rocky, sloppy, shrubby or forested areas (Nilson, 1972; Ercisli, 2005, 2007). With its fruits widely used in the food industry and with a strong root system and fragrant white-topink flowers, rosehip shrubs are used in landscape arrangements and also for prevent soil erosion. The rosehip fruit is formed through flesh out of receptacles, has egg-like, elliptical or circular shapes and the fruit surface may either be hairy or hairless, while the fruit colour may be yellow, orange or shiny red (Ilisulu, 1992; Ercisli, 2007).

The fruits are generally collected from the natural habitats. Besides the fruit itself, different parts of the plant are primarily used in food, drug, cosmetic and dye industries. In the food industry, rosehip is used for processing into marmalades, jelly, sauce, jam, fruit juice and confectionary products, various beverages, herbal teas and alcoholic beverages. Sedative seeds are used in the feed industry, fruit juices, dairy products and infant formulas (Ercisli, 2005). Various processing systems are employed in processing of rosehip fruits. Such systems are designed and developed directly based on the fruit physical characteristics. The design of classification and packaging systems largely relies on the fruit length, diameter, projection area and volumelike dimensional attributes. The fruit shape should be defined in mechanical sieving systems. Pneumatic separation and mechanical deseeding systems are also designed based on the fruit shape and dimensional properties (Say1nc1 et al., 2015b). The shape definition of agricultural commodities is a physical competence of the product.

More recently, there has been an increasing interest in wild edible fruits including rosehip, which possess several properties that are beneficial for human health. Wild edible fruits including rosehip have unique flavours, high antioxidant, vitamins, minerals, fibre and folic acid content. In addition to fresh consumption, wild edible fruits are widely used in beverages, ice cream, yogurt, jams, jellies and many other food products. A number of wild edible fruits are used by the rural and tribal populations and significantly contribute to their livelihood (Dogan et al., 2014; Gundogdu et al., 2014; Engin and Mert, 2020; Gecer et al., 2020; Kaskoniene et al., 2020).

Rosehip fruits are used for treatment of diabetes, stomach and kidney disorders (Kostic, 1994), in reducing the formation of cancer cells (Olsson et al., 2004), prevention of cardiovascular diseases (Ninomya et al., 2007), as anti-inflammatory (Deliorman et al., 2007), antidepressant (Pieroni and Quave, 2005), as a blood cleanser and against inflammatory diseases (Ozkan et al., 2004).

Rosehip fruits are quite rich in antioxidants (Su et al., 2007), total phenolics (Hvattum, 2002), vitamin C (Uggla et al., 2005), carotenoids (HorneroMendez and Minquez-Mosquera, 2000), sugars (Uggla et al., 2005) and minerals (Szentmihalyi et al., 2002).
The therapeutic effects of the fruits are mostly attributed to its phenolics composition. Phenolic substances have a large range of biochemical activity like anti-mutagenic and anti-carcinogenic effects (Tapiero et al., 2002; Nakamura et al., 2003).

Previous studies conducted on nutritional composition of rosehip fruits revealed that the rosehip species offered an important source of nutrients. According to the United States Department of Agriculture (USDA) report published in 2019, $100 \mathrm{~g}$ of rosehip fruit contains $38.22 \mathrm{~g}$ carbohydrate, $24.1 \mathrm{~g}$ fibre, $1.6 \mathrm{~g}$ protein, $426 \mathrm{mg}$ vitamin $\mathrm{C}, 4,345 \mathrm{IU}$ vitamin A, $5.84 \mathrm{mg}$ vitamin $\mathrm{E}, 25.9 \mu \mathrm{g}$ vitamin $\mathrm{K}, 2,350 \mu \mathrm{g}$ beta carotene, $429 \mathrm{mg}$ potassium, $169 \mathrm{mg}$ calcium, $69 \mathrm{mg}$ magnesium and $61 \mathrm{mg}$ phosphorus (FOODDATA CENTRAL, 2019).

Parallel to the increasing interest in rosehip fruits, the number of processing facilities is also increasing. Therefore, the physical characteristics of the available genotypes should be put forth for production and development of processing technologies. Prospective studies on this issue may provide significant contributions to processing technology. On the other hand, a broadened range of products may lead to the emergence of an important source of income for local farmers. However, identification of genotypes to be included in cropping patterns for different purposes is a significant issue.

The primary objective of the present study was to determine the variation in the biochemical traits of 25 rosehip (Rosa canina L.) genotypes with different characteristics and naturally encountered in Mesudiye (Ordu) and Talas (Kayseri) districts. The secondary objective was to determine the variations in shapes, physical aspects of these genotypes and to identify similar ones. So, the primary target was to put forth the genotypes with superior antioxidant activity and phenolic substances and to offer a genetic source for further studies. The secondary target was to generate a database for shape and physical traits of these genotypes to be used in design of rosehip processing technologies.

\section{MATERIALS AND METHODS}

\section{Material locations}

Seed-propagated rosehip genotypes in Mesudiye (Ordu) and Talas (Kayseri) districts constituted the material of the present study. Mesudiye has an altitude of $1,135 \mathrm{~m}$ and a transitional climate between semiarid and semi-humid climates. Talas has an altitude of 1,148 $\mathrm{m}$ and a dominant terrestrial Central Anatolia climate (Anonymous, 2020). The initial 16 genotypes are located in Mesudiye and 9 genotypes are located in Talas (a total of 25 genotypes were used in this study). From each genotype, 100 fruits were collected, placed into plastic bags and brought to the laboratory in a cooler. 


\section{Biochemical analyses}

Biochemical analyses were conducted in 5 replicates with 20 fruits in each replicate. The fruits were deseeded with a stainless-steel blade and homogenised in a food blender. Homogenised fruit samples were placed into falcon tubes (about $50 \mathrm{~g}$ ) and preserved at $-20^{\circ} \mathrm{C}$ until the performance of bioactive analyses.

\section{DPPH antioxidant activity (free radical scavenging activity)}

Fruit DPPH antioxidant activity was determined with use of the modified version of Brand-Williams et al. (1995) method. For analysis, 0.26 mM DPPH (1,1-diphenyl-2picryl-hydrazyl) solution was prepared. About $100 \mu \mathrm{L}$ fruit extract was supplemented with $2,900 \mu \mathrm{L}$ ethyl alcohol and $1 \mathrm{~mL}$ DPPH solution, vortex-mixtures and kept in the dark for $30 \mathrm{~min}$. Following incubation, sample absorbance was read in a spectrophotometer at $517 \mathrm{~nm}$ wavelength. The resultant absorbance values were expressed in $\mu \mathrm{mol}$ Trolox $\left(10-100 \mu \mathrm{mol} \cdot \mathrm{L}^{-1}\right)$ equivalent fresh weight $\left(\mu \mathrm{mol} \cdot \mathrm{kg}^{-1}\right)$.

\section{Total flavonoids}

The total flavonoids in the sample were determined following the method of Chang et al. (2002). About $1,000 \mu \mathrm{L}$ of fruit extract sample was supplemented with $3.3 \mathrm{~mL}$ methanol, then supplemented with $0.1 \mathrm{~mL} 10 \%$ $\mathrm{AlCl}_{3} \cdot 6 \mathrm{H}_{2} \mathrm{O}$ and $\mathrm{CH}_{3} \mathrm{COOK}$. Sample absorbance was read in a spectrophotometer at $415 \mathrm{~nm}$ wavelength. Total flavonoids were expressed in quercetin equivalent $(\mathrm{QE})$, $\mathrm{mg} \cdot \mathrm{kg}^{-1}$ fresh weight.

\section{Total phenolics}

Fruit total phenolics was determined with the use of Folin-Ciocalteu reagent. Initially, $500 \mu \mathrm{L}$ of fresh fruit extract was supplemented with $4.2 \mathrm{~mL}$ distilled water, then with $100 \mu \mathrm{L}$ Folin-Ciocalteu reagent and $2 \%$ sodium carbonate $\left(\mathrm{Na}_{2} \mathrm{CO}_{3}\right)$. The resultant solution was incubated for $2 \mathrm{~h}$ and readings were performed in a spectrophotometer at $760 \mathrm{~nm}$ wavelength. Total phenolics was expressed in gallic acid equivalent $\mathrm{mg} \cdot \mathrm{kg}^{-1}$ (fresh weight) (Beyhan et al., 2010).

\section{Imaging system and sampling}

Randomly, 35 samples were taken from each genotype, which was encoded as G1-G25 (Figure 1) to determine the shape and dimensional traits. Samples were placed on a fibreglass plate in a $5 \times 7$ matrix arrangement and *tiff extension images were taken using a Nikon D90 model camera. Artificial lighting was provided beneath the plate to prevent shadow formation while imaging (Ercisli et al., 2012). The camera was fixed on a tripod and images were taken from $50 \mathrm{~cm}$ above the samples. An external shutter release was used to prevent vibration of the camera. Imaging was conducted at both horizontal and vertical orientation for 3-D dimensional analysis.

\section{Shape and dimensional properties}

The SigmaScan Pro v.5.0 software was used to determine the shape and dimensional properties of the rosehip genotypes. With the image processing analysis, length $(L, \mathrm{~mm})$, width $(W, \mathrm{~mm})$, thickness $(T, \mathrm{~mm})$, projected area $\left(P A, \mathrm{~mm}^{2}\right)$, equivalent diameter $(E D$, $\mathrm{mm})$, perimeter $(P, \mathrm{~mm})$ and circularity $(C)$ values were directly measured. The dimensions and area measures are presented in Figure 2. With the use of $L, W$ and $T$ values, geometric mean diameter $\left(D_{g}, \mathrm{~mm}\right)$, horizontal elongation $\left(E_{h}\right)$ and vertical elongation $\left(E_{v}\right)$ values were calculated using Eqs (1)-(3), respectively (Mohsenin, 1986; Sayınc1 et al., 2015a).

$$
D_{g}=\sqrt[3]{L \cdot W \cdot T}
$$

$E_{h}=\frac{L}{W}$

$E_{v}=\frac{W}{T}$

Surface area $\left(S A, \mathrm{~mm}^{2}\right)$ and sphericity $(\varphi, \%)$ of rosehip genotypes were calculated as a function of geometric mean diameter using Eqs (4) and (5), respectively (Mohsenin, 1986; Demir et al., 2020).

$S A=\pi \cdot D_{g}^{2}$
$\varphi=\frac{D_{g}^{2}}{L} \cdot 100$

The horizontal area measured over 2-D plane is the so-called projected area. Circularity of the genotypes $(C)$ was calculated as a function of projected area $(P A$, $\mathrm{mm}^{2}$ ) and perimeter $(P, \mathrm{~mm})$ using Eq. (6). A circularity value of 1 indicates a full-circular shape of the material (Sayınc1 et al., 2015a).

$$
C=4 \cdot \pi \cdot \frac{P A}{P^{2}}
$$

The volume $(V)$ of geometrically ellipse-like fruits was calculated using the formula for the volume of an ellipse Eq. (7). The ratio of the projected area at horizontal orientation to geometric surface area was defined as the surface closure rate (SCR) and calculated using Eq. (8). When $L$ and $W$ are the same, the SCR equation is defined as projected area/area of circle. Otherwise, when $L$ and $W$ are different, the SCR value is projected arealarea of ellipse. An SCR value of 1 indicates that the projected area of the fruit closed the entire surface area calculated based on the largest dimensions (Demir et al., 2019).

$$
\begin{aligned}
& V=\frac{1}{6} \cdot \pi \cdot L \cdot W \cdot T \\
& S C R=\frac{4 \cdot P A}{\pi \cdot L \cdot W}
\end{aligned}
$$




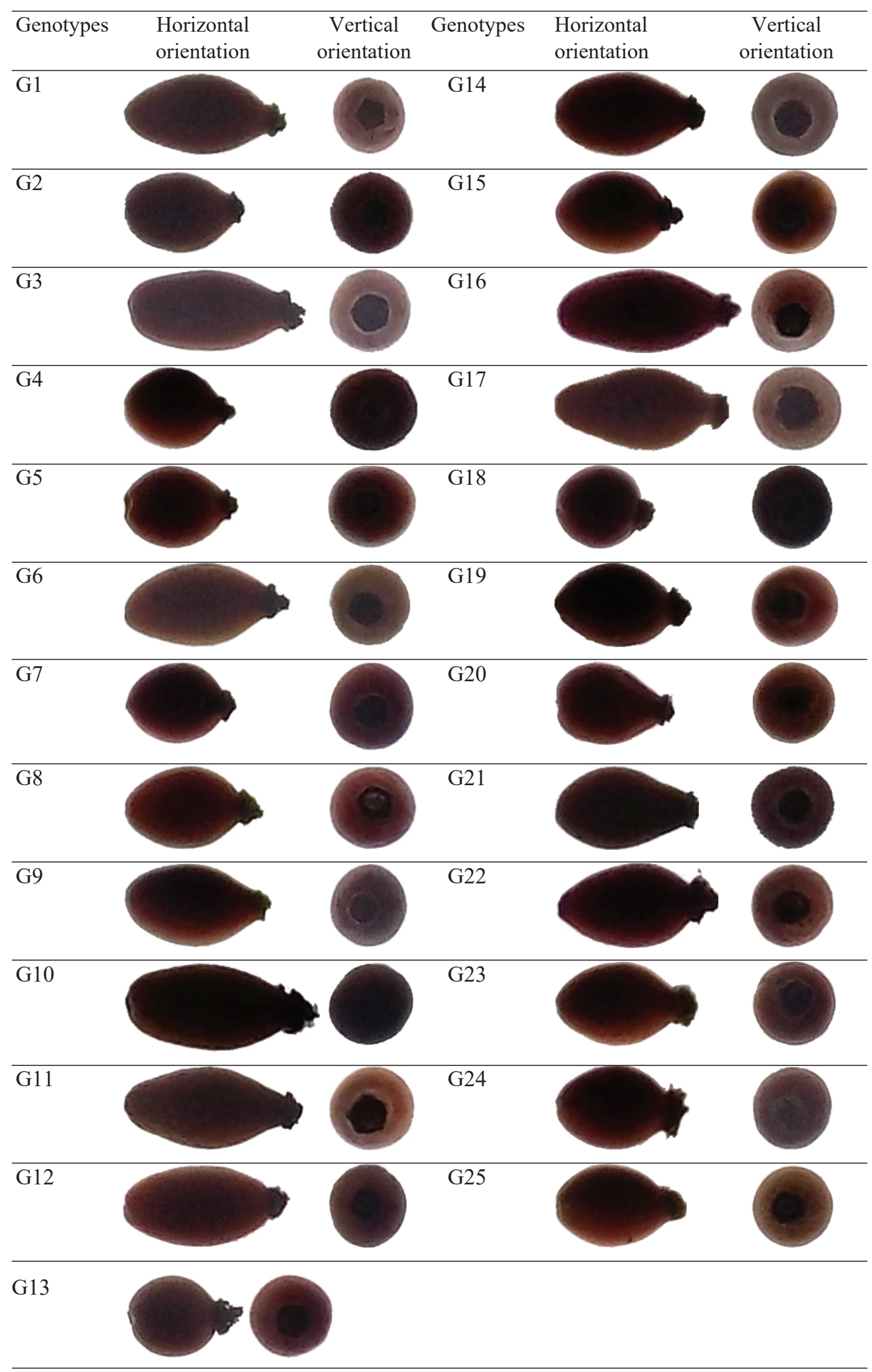

Figure 1. Rosehip genotypes displayed in horizontal and vertical orientation.

\section{Elliptical Fourier analysis}

For elliptical Fourier analysis (EFA), at least 70 images of each genotype were used. Analyses were conducted using the SHAPE (version 1.03) software (Iwata and Ukai, 2002). This analysis comprises definition of contours of a closed shape, identification 


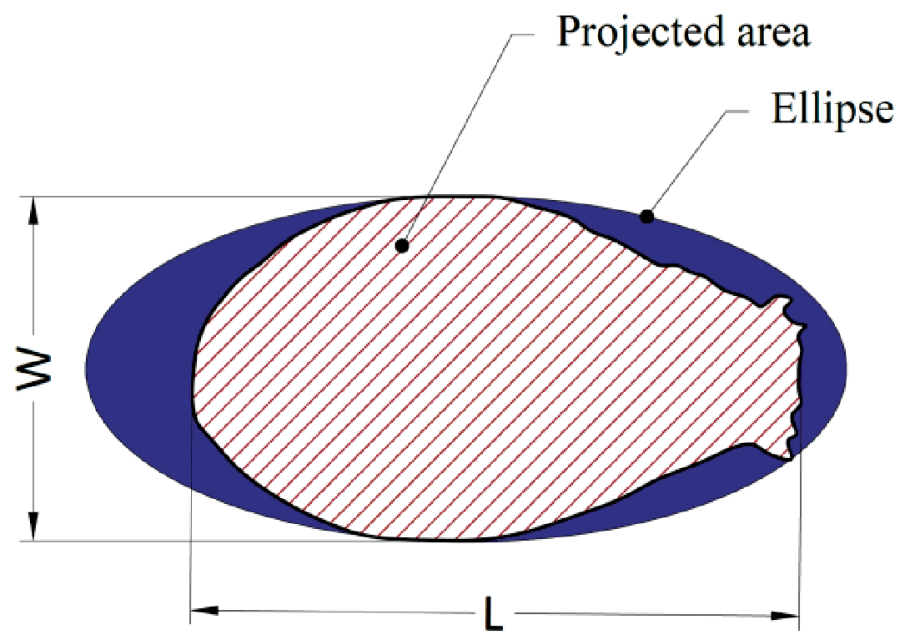

Horizontal orientation

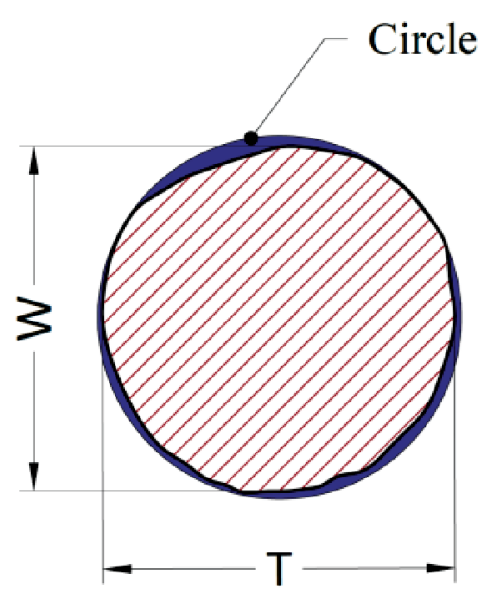

Vertical orientation

Figure 2. Length and area measurements of rosehip genotypes.

of the $x$ and $y$ coordinates of the points on the curve constituting a shape, conversion of coordinate values into a mathematical function and identification of function coefficients (Sayınc1, 2016). The function coefficients depend on the number of harmonics and the present analyses were conducted over 20 harmonics. Each harmonic generates four Fourier coefficients $\left(a_{n}, b_{n}, c_{n}\right.$ and $\left.d_{n}\right)$. The $a_{n}$ and $b_{n}$ coefficients correspond to the $x$ coordinate and the $c_{n}$ and $d_{n}$ coefficients correspond to the $y$ coordinate of the curve (Neto et al., 2006; Ozkan-Koca, 2012).

For image processing, rosehip image files were converted into 24-bit *bmp format. Four modules were used to obtain the shape data. In the Module I (ChainCoder), image processing and shape contour codes were generated. In Module II (Chc2Nef), contours were normalised and elliptic Fourier descriptors were obtained. In Module III (PrinComp), descriptors were subjected to principal component (PC) analysis and PC scores were obtained. In Module IV (PrinPrint), the shape variations of fruit image contours were visualised.

\section{Statistical analyses}

Statistical analyses were conducted using the SPSS 23.0 software. Means for biochemical traits were compared using Duncan's test at a 5\% significance level. The shape and dimensional properties of rosehip genotypes were explained with box-plot graphs. On these graphs, extreme values, means and medians were indicated with symbols and mean, standard deviation, minimum and maximum values of each variable were presented. Extreme values were not included in the minimum and maximum values. Differences in shape and dimensional traits of rosehip genotypes were identified with the use of PC analysis. The most significant variables designating the differences in shape and dimensional traits were ordered based on the factor loads. Differences between the genotypes were presented in scatter plots based on component scores. The contour codes obtained through EFA were normalised and multivariate variance analysis (MANOVA) was conducted to test the shape differences in the genotypes. The PAST v.4.02 software was used for MANOVA. The shape differences in the genotypes were explained by Hotelling's paired comparison tests, including verified Bonferroni values and Mahalanobis distances. In linear discriminant analysis conducted with the use of PC scores, the functions revealing shape differences of the genotypes were determined and similarity relations between the genotypes were presented in scatter plots. Such similarities were also put forth by hierarchical clustering analysis with the use of Euclidean similarity index and shape-similar genotypes were grouped on a dendrogram.

\section{RESULTS AND DISCUSSION}

\section{Biochemical analyses}

Differences in antioxidant activity, total flavonoids and total anthocyanins of seed-propagated rosehip fruits collected from two different locations were found to be significant $(p<0.05)$ (Table 1).

Antioxidant activity of rosehip genotypes varied from $39.510 \mathrm{mmol} \cdot \mathrm{kg}^{-1}$ (G6) to $72.673 \mathrm{mmol} \cdot \mathrm{kg}^{-1}$ (G19). In terms of antioxidant activity, G19 was respectively followed by G20 $\left(67.944 \mathrm{mmol} \cdot \mathrm{kg}^{-1}\right), \mathrm{G} 25$ $\left(67.705 \mathrm{mmol} \cdot \mathrm{kg}^{-1}\right)$ and G24 (64.864 mmol $\left.\cdot \mathrm{kg}^{-1}\right)$. There were significant variations in antioxidant activity of the genotypes and those collected from Kayseri province generally had greater antioxidant activity. In previous studies, rosehip genotypes showed strong DPPH radical (2,2-diphenyl-1-picrylhydrazyl) scavenging activity (Yolcu, 2010). Using the DPPH method, the antioxidant activity values for methanol 
Table 1. Biochemical characteristics of rosehip genotypes (fresh weight base).

\begin{tabular}{lccc}
\hline Genotypes & $\begin{array}{c}\text { Antioxidant activity } \\
(\mathrm{DPPH})\left(\mathrm{mmol} \mathrm{TE} \cdot \mathrm{kg}^{-1}\right)\end{array}$ & $\begin{array}{c}\text { Total flavonoids } \\
\left(\mathrm{mg} \mathrm{QE} \cdot \mathrm{kg}^{-1}\right)\end{array}$ & $\begin{array}{c}\text { Total phenolics } \\
\left(\mathrm{mg} \mathrm{GAE} \cdot \mathrm{kg}^{-1}\right)\end{array}$ \\
\hline G1 & $46.777 \pm 0.145 \mathrm{n}$ & $523.20 \pm 5.41 \mathrm{jk}$ & $63,495.40 \pm 230.94 \mathrm{ih}$ \\
$\mathrm{G} 2$ & $46.462 \pm 0.204 \mathrm{n}$ & $708.40 \pm 3.91 \mathrm{~g}$ & $63,452.80 \pm 255.46 \mathrm{ih}$ \\
G3 & $51.042 \pm 0.139 \mathrm{k}$ & $517.40 \pm 4.47 \mathrm{jk}$ & $71,282.80 \pm 256.12 \mathrm{~d}$ \\
$\mathrm{G} 4$ & $52.186 \pm 0.128 \mathrm{j}$ & $500.80 \pm 6.18 \mathrm{kl}$ & $67,119.80 \pm 229.01 \mathrm{f}$ \\
G5 & $51.334 \pm 0.280 \mathrm{k}$ & $402.20 \pm 4.28 \mathrm{o}$ & $48,936.20 \pm 147.12 \mathrm{n}$ \\
G6 & $39.510 \pm 0.172 \mathrm{o}$ & $615.40 \pm 5.94 \mathrm{~h}$ & $39,103.20 \pm 135.65 \mathrm{~s}$ \\
G7 & $48.791 \pm 0.321 \mathrm{~lm}$ & $287.80 \pm 6.53 \mathrm{r}$ & $41,221.40 \pm 235.79 \mathrm{r}$ \\
G8 & $64.726 \pm 0.227 \mathrm{c}$ & $560.00 \pm 3.82 \mathrm{i}$ & $63,220.00 \pm 477.88 \mathrm{i}$ \\
G9 & $55.626 \pm 0.209 \mathrm{~h}$ & $480.80 \pm 6.731$ & $50,449.80 \pm 443.70 \mathrm{~m}$ \\
G10 & $61.904 \pm 0.234 \mathrm{~d}$ & $292.80 \pm 1.77 \mathrm{r}$ & $57,572.20 \pm 443.72 \mathrm{j}$ \\
G11 & $452.60 \pm 0.92 \mathrm{~m}$ & $38,519.40 \pm 95.26 \mathrm{~s}$ \\
G12 & $46.446 \pm 0.355 \mathrm{n}$ & $342.20 \pm 3.15 \mathrm{p}$ & $39,297.40 \pm 323.95 \mathrm{~s}$ \\
G13 & $46.958 \pm 0.243 \mathrm{n}$ & $46,377.80 \pm 283.56 \mathrm{o}$ \\
G14 & $52.887 \pm 0.203 \mathrm{i}$ & $407.80 \pm 2.59 \mathrm{no}$ & $45,989.00 \pm 454.78 \mathrm{o}$ \\
G15 & $56.329 \pm 0.292 \mathrm{~g}$ & $426.80 \pm 5.90 \mathrm{~g}$ & $58,534.00 \pm 291.88 \mathrm{j}$ \\
G16 & $58.241 \pm 0.205 \mathrm{f}$ & $985.20 \pm 12.41 \mathrm{~d}$ & $44,822.20 \pm 90.64 \mathrm{p}$ \\
G17 & $53.422 \pm 0.227 \mathrm{i}$ & $1,686.20 \pm 4.55 \mathrm{a}$ & $66,139.40 \pm 326.93 \mathrm{k}$ \\
G18 & $56.142 \pm 0.172 \mathrm{gh}$ & $1,505.20 \pm 35.01 \mathrm{~b}$ & $62,851.80 \pm 304.91 \mathrm{i}$ \\
G19 & $59.361 \pm 0.273 \mathrm{e}$ & $1,095.80 \pm 10.00 \mathrm{c}$ & $79,080.60 \pm 267.63 \mathrm{a}$ \\
G20 & $72.673 \pm 0.198 \mathrm{a}$ & $754.40 \pm 4.05 \mathrm{f}$ & $73,391.60 \pm 455.63 \mathrm{~b}$ \\
G21 & $67.944 \pm 0.316 \mathrm{~b}$ & $537.60 \pm 3.73 \mathrm{ij}$ & $68,647.00 \pm 272.68 \mathrm{e}$ \\
G22 & $48.318 \pm 0.160 \mathrm{~m}$ & $636.60 \pm 7.29 \mathrm{~h}$ & $64,285.20 \pm 894.97 \mathrm{gh}$ \\
G23 & $59.838 \pm 0.257 \mathrm{e}$ & $52,998.00 \pm 177.861$ \\
G24 & $49.226 \pm 0.1631$ & $72,313.20 \pm 252.59 \mathrm{c}$ \\
G25 & $64.864 \pm 0.173 \mathrm{c}$ & $64,672.60 \pm 253.87 \mathrm{~g}$ \\
\hline
\end{tabular}

*The difference between the averages indicated by different letters in the same column is significant $(p<0.05)$.

QE, quercetin equivalent.

extracts of samples were reported to be between $79.16 \%$ and $87.78 \%$ (Fattahi et al., 2012) and between 62.6\% and 93.4\% (Orhan et al., 2012). The antioxidant capacity of rosehip fruits was also determined through DPPH reducing power of the solution prepared with trolox or ascorbic acid standards. In such studies, the DPPH radical scavenging activity of rosehip fruits was reported to be $278.90 \mu \mathrm{mol} \mathrm{TE} \cdot \mathrm{g}^{-1}$ for methanol extract samples (Demir et al., 2014), respectively, as $32.7 \mu \mathrm{g}$ $\mathrm{TE} \cdot \mathrm{mL}^{-1}$ and $21.7 \mu \mathrm{g} \mathrm{TE} \cdot \mathrm{mL}^{-1}$ for water and methanol extracts (Nadpal et al., 2016), as between $4.83 \mu \mathrm{mol}$ $\mathrm{AAE} \cdot \mathrm{g}^{-1}$ and $5.26 \mu \mathrm{mol} \mathrm{AAE} \cdot \mathrm{g}^{-1}$ (Kasun, 2017) and as between $14.2 \mu \mathrm{g} \mathrm{TE} \cdot \mathrm{mL}^{-1}$ and $31.1 \mu \mathrm{g} \mathrm{TE} \cdot \mathrm{mL}^{-1}$ (Beyhan et al., 2017) for water-methanol (1/1) extracts. Layina-Pathirana et al. (2006) indicated that DPPH free-radical scavenging-based analysis was more advantageous over the other methods in antioxidant activity analysis. On the other hand, different methods have been used to determine the antioxidant activity of rosehip fruits. For the antioxidant capacity of rosehip fruits, Su et al. (2007) used the $\mathrm{ABTS}^{+}$method and reported the values to be between $190 \mu \mathrm{mol} \mathrm{TE} \cdot \mathrm{g}^{-1}$ and $370 \mu \mathrm{mol} \mathrm{TE} \cdot \mathrm{g}^{-1}$; Demir et al. (2014) reported the antioxidant activity to be $35.51 \mu \mathrm{mol} \mathrm{TE} \cdot \mathrm{g}^{-1}$ with $\mathrm{ABTS}^{+}$method and as $301.80 \mu \mathrm{mol} \mathrm{TE} \cdot \mathrm{g}^{-1}$ with FRAP method; Murathan et al. (2016) used the FRAP method and reported the value as $97.75 \mu \mathrm{mol} \mathrm{TE} \cdot \mathrm{g}^{-1}$; Eroglu and Oguz (2018) also used the FRAP method and reported the values to be between $56.80 \mu \mathrm{mol} \mathrm{TE} \cdot \mathrm{g}^{-1}$ and $13.60 \mu \mathrm{mol} \mathrm{TE} \cdot \mathrm{g}^{-1}$. The values of the present study related to DPPH activity were greater than the majority of previous studies and the differences were mainly attributed to the difference in the ecologies in which the plants grow, growing conditions, ripening levels and extraction methods (Wu et al., 2004; Ozturk et al., 2009; Alp et al., 2016).

The greatest total flavonoids were obtained from the genotypes $\mathrm{G} 18\left(1,686.20 \mathrm{mg} \mathrm{QE} \cdot \mathrm{kg}^{-1}\right)$ and $\mathrm{G} 19$ $\left(1,505.20 \mathrm{mg} \mathrm{QE} \cdot \mathrm{kg}^{-1}\right)$ collected from Kayseri province. The lowest values were obtained from the genotypes G7 (287.80 $\left.\mathrm{mg} \mathrm{QE} \cdot \mathrm{kg}^{-1}\right)$ and G11 (292.80 mg $\mathrm{QE} \cdot \mathrm{kg}^{-1}$ ) (Table 1). The present findings revealed quite a large variation in the total flavonoids of rosehip fruits. Similar findings were also reported in previous studies conducted with rosehip fruits. The total flavonoids of rosehip genotypes collected from different parts of Iran were reported as $10.4 \mathrm{mg} \mathrm{QE} \cdot \mathrm{g}^{-1}$ (Montazeri et al., 2011); as between $41.0 \mathrm{mg} \mathrm{QE} \cdot 100 \mathrm{~g}^{-1}$ and $72.0 \mathrm{mg}$ QE · $100 \mathrm{~g}^{-1}$ in Poland (Adamczak et al., 2012); as $196.26 \mathrm{mg}$ rutin $\cdot \mathrm{g}^{-1}$ (Tumbas et al., 2012) and $38.52 \mathrm{mg}$ $\mathrm{QE} \cdot \mathrm{g}^{-1}$ (Paunovic et al., 2019) in Serbia; as between $101.3 \mathrm{mg} \mathrm{QE} \cdot 100 \mathrm{~g}^{-1}$ and $163.2 \mathrm{mg} \mathrm{QE} \cdot 100 \mathrm{~g}^{-1}$ (Roman 
et al., 2013) and as between $211.8 \mathrm{mg} \mathrm{QE} \cdot 100 \mathrm{~g}^{-1}$ and $672.67 \mathrm{mg} \mathrm{QE} \cdot 100 \mathrm{~g}^{-1}$ (Soare et al., 2015) in Romania; as between $151.0 \mathrm{mg} \mathrm{QE} \cdot 100 \mathrm{~g}^{-1}$ and $241.0 \mathrm{mg}$ QE $\cdot 100 \mathrm{~g}^{-1}$ in Sivas province of Turkey (Beyhan et al., 2017) and as between $29.5 \mathrm{mg}$ QE $\cdot 100 \mathrm{~g}^{-1}$ and $36.3 \mathrm{mg} \mathrm{QE} \cdot 100 \mathrm{~g}^{-1}$ in Samsun province of Turkey (Tastekin, 2017). The differences in total flavonoids of rosehip fruits were mainly attributed to the differences in genotypes, ecological conditions and extraction methods.

Total phenolics of the genotypes varied between 38,519.40 (G11) $\mathrm{mg} \mathrm{GAE} \cdot \mathrm{kg}^{-1}$ and 79,080.60 (G19) $\mathrm{mg}$ GAE $\cdot \mathrm{kg}^{-1}$ with a large variation (Table 1). In gallic acid equivalent fresh weight, the present total phenolics were greater than the findings of Fattahi et al. (2012), who reported the total phenolics in Iran as between $1,764.8 \mathrm{mg}$ and 2,256.5 mg; the findings of Demir et al. (2014) (31,080 mg) and Beyhan et al. (2017) (between $3,400 \mathrm{mg}$ and 4,640 $\mathrm{mg}$ ) in Turkey were analogous with the findings of Yolcu (2010) (41,846 $\left.\mathrm{mg} \mathrm{GAE} \cdot \mathrm{kg}^{-1}\right)$, Murathan et al. (2016) $\left(62,980 \mathrm{mg} \mathrm{GAE} \cdot \mathrm{kg}^{-1}\right)$ and Tastekin (2017) $\left(68,454 \mathrm{mg}\right.$ GAE $\left.\cdot \mathrm{kg}^{-1}\right)$ in Turkey, Soare et al. (2015) (41,750 $\left.\mathrm{mg} \mathrm{GAE} \cdot \mathrm{kg}^{-1}\right)$ in Romania and Taneva et al. (2016) (69,000 $\mathrm{mg}$ GAE $\left.\cdot \mathrm{kg}^{-1}\right)$ in Bulgaria. On the other hand, Yilmaz and Ercisli (2011) reported the total phenolics of rosehip fruits grown in Turkey as between 78,000 $\mathrm{mg}$ GAE $\cdot \mathrm{kg}^{-1}$ and $102,000 \mathrm{mg} \mathrm{GAE} \cdot \mathrm{kg}^{-1}$, and Aptin et al. (2013) reported the total phenolics of 30 rosehip genotypes collected from different regions of Iran as between $57,000 \mathrm{mg} \mathrm{GAE} \cdot \mathrm{kg}^{-1}$ and $152,000 \mathrm{mg} \mathrm{GAE} \cdot \mathrm{kg}^{-1}$. In other studies, conducted on rosehip genotypes, the total phenolics were reported as $99,820 \mathrm{mg} \mathrm{GAE} \cdot \mathrm{kg}^{-1}$ in Gümüşhane province of Turkey (Yildiz and Alpaslan, 2012) and as 90,510 $\mathrm{mg} \mathrm{GAE} \cdot \mathrm{kg}^{-1}$ in Serbia (Paunovic et al., 2019).

The present findings on the antioxidant activity, total flavonoids and total phenolics revealed that there were significant variations between the genotypes and such values were influenced by the province from where they were collected and also the background of the genotypes. Previous studies also indicated that genotypes, altitude, soil and climate conditions, ecological conditions, fruit ripening levels and extraction methods strongly affect fruit contents (Serce et al., 2010; Eroglu and Oguz, 2018).

\section{Shape and dimensional traits}

The general shape and dimensional traits of rosehip genotypes are presented in Figure 3. In terms of dimensional traits, fruit lengths were generally greater than the width and thickness values. The present values revealed that rosehip genotypes had an ellipse-like shape. The present findings on the dimensional traits comply with the findings of Demir and Özcan (2001). Equivalent diameter is calculated based on the projected area. The geometric mean diameter had a lower average than the equivalent diameter. Since the dimensional traits were measured on a 3-D plane, the fruit diameter is the best explained with the geometric mean diameter (Sayınc1 et al., 2015b).

The average projected area measured at horizontal orientation was lower than the value measured at vertical orientation. This trait indicated that the rosehip fruits were positioned at a horizontal plane in dimensioning, classification, drying etc. The surface area plays a great role in calculation of the heat transfer rates in drying systems (Bart-Plange et al., 2012). Compared to cherry laurel fruits with an average surface area of $1,230 \mathrm{~mm}^{2}$ (Sayınc1 et al., 2015a), rosehip fruits had a lower average surface area $\left(674.6 \mathrm{~mm}^{2}\right)$. In this sense, it was thought that the drying duration of rosehip fruits would be shorter compared to cherry laurel fruits. In terms of fruit volume, cherry laurel $\left(4.13 \mathrm{~cm}^{3}\right)$ has 2.5 times greater volume than rosehip fruits $\left(1.66 \mathrm{~cm}^{3}\right)$ (Sayınc1 et al., 2015a). The average perimeter of rosehip fruits was calculated as $56.4 \mathrm{~mm}$ and such value was quite close to the average perimeter of cornelian cherry fruits (54.3 mm) (Demir et al., 2020).

Greater elongation at horizontal orientation than at vertical orientation revealed that the fruit shape looked like an ellipse. Thus, the circularity and sphericity averages were calculated as $0.712 \%$ and $71.4 \%$, respectively. In terms of sphericity, rosehip genotypes were close to cornelian cherry genotypes (78.8\%) (Demir et al., 2020). The SCRs varied between 0.83 and 0.98 . This ratio may be especially significant in terms of attachment of a fruit onto a perforated surface of pneumatic systems with the aid of air flow. A ratio of 1 indicates that the hole was fully closed by the fruit.

\section{PC analysis}

The factor loads for shape and dimensional traits are provided in Table 2. Three PCs were able to explain $98.571 \%$ of the total variation. The most important factors differentiating rosehip genotypes were identified as dimensional traits (surface area, geometric mean diameter and volume) gathered under PC1. The factors included in PC2 and PC3 define the shape traits of the genotypes (elongation, sphericity, circularity and $\mathrm{SCR}$ ). Among these variables, it is remarkable that the elongation factor had negative correlations with PC2.

According to Figure 4A, in terms of surface area, geometric mean diameter and volume, the genotypes G11, G12, G15 and G24 had the greatest averages. The genotypes G3, G8, G9, G13 and G16 had the least averages and were placed on the left of PC1 axis. The greatest sphericity and circularity averages were observed in genotypes G4, G5, G7, G13 and G18. The greatest elongation averages, explaining the ratio of length and width dimensions, were observed in genotypes G3, G11, G16 and G17. According to Figure 4B, the greatest SCRs were observed in genotypes G3, G9, G12, G16, G18 and G21 and the genotypes with the lowest averages were presented in a circle beneath the PC3 axis. 

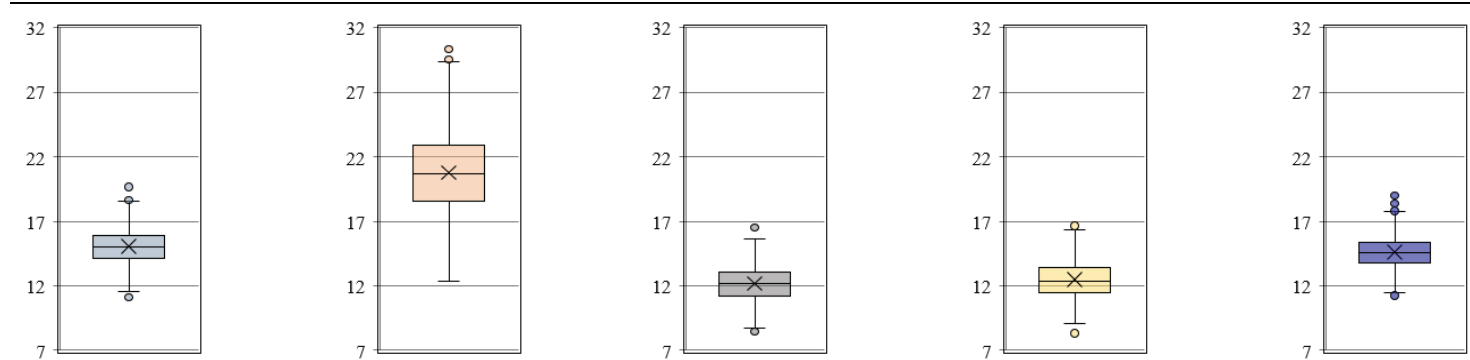

\begin{tabular}{lllll}
\hline Eq. diameter $(\mathrm{mm})$ & Length $(\mathrm{mm})$ & Width $(\mathrm{mm})$ & Thickness $(\mathrm{mm})$ & GMD $(\mathrm{mm})$ \\
\hline Mean \pm SD: $15.1 \pm 1.4$ & Mean \pm SD: 20.8 \pm 3.1 & Mean \pm SD: 12.2 \pm 1.3 & Mean \pm SD: 12.5 \pm 1.4 & Mean \pm SD: 14.6 \pm 1.3 \\
Min-max: $11.4-18.6$ & Min-max: 12.0-29.5 & Min-max: 8.5-15.8 & Min-max: 8.6-16.3 & Min-max: 11.3-17.8 \\
\hline
\end{tabular}
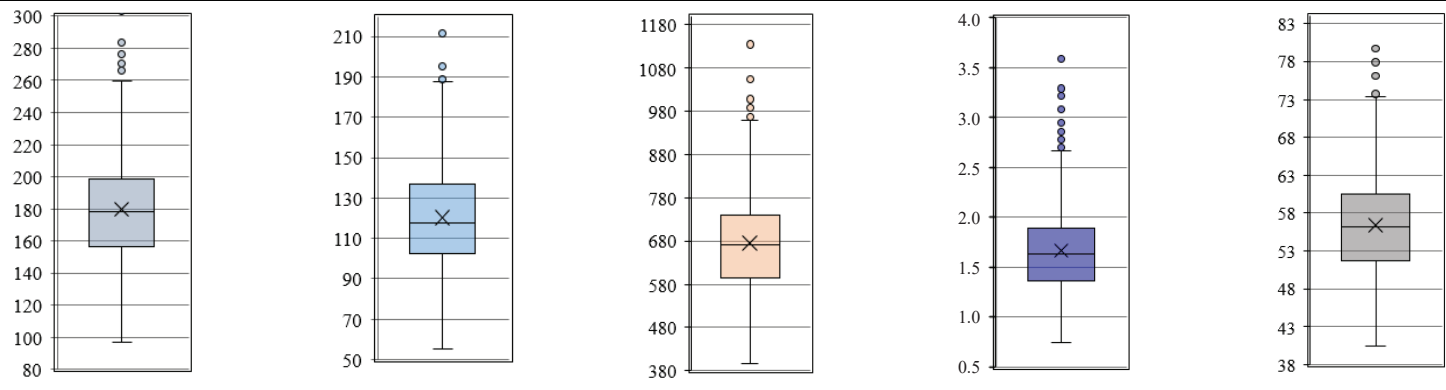

Proj. area at hor. $\left(\mathrm{mm}^{2}\right) \quad$ Proj. area at vert. $\left(\mathrm{mm}^{2}\right) \quad$ Surface area $\left(\mathrm{mm}^{2}\right)$

Volume $\left(\mathrm{cm}^{3}\right)$

Perimeter $(\mathrm{mm})$

Mean \pm SD: $179.7 \pm 33.2$ Mean \pm SD: $120.4 \pm 25.1$ Mean \pm SD: $674.6 \pm 115.7$ Mean \pm SD: $1.666 \pm 0.432$ Mean \pm SD: $56.4 \pm 6.5$

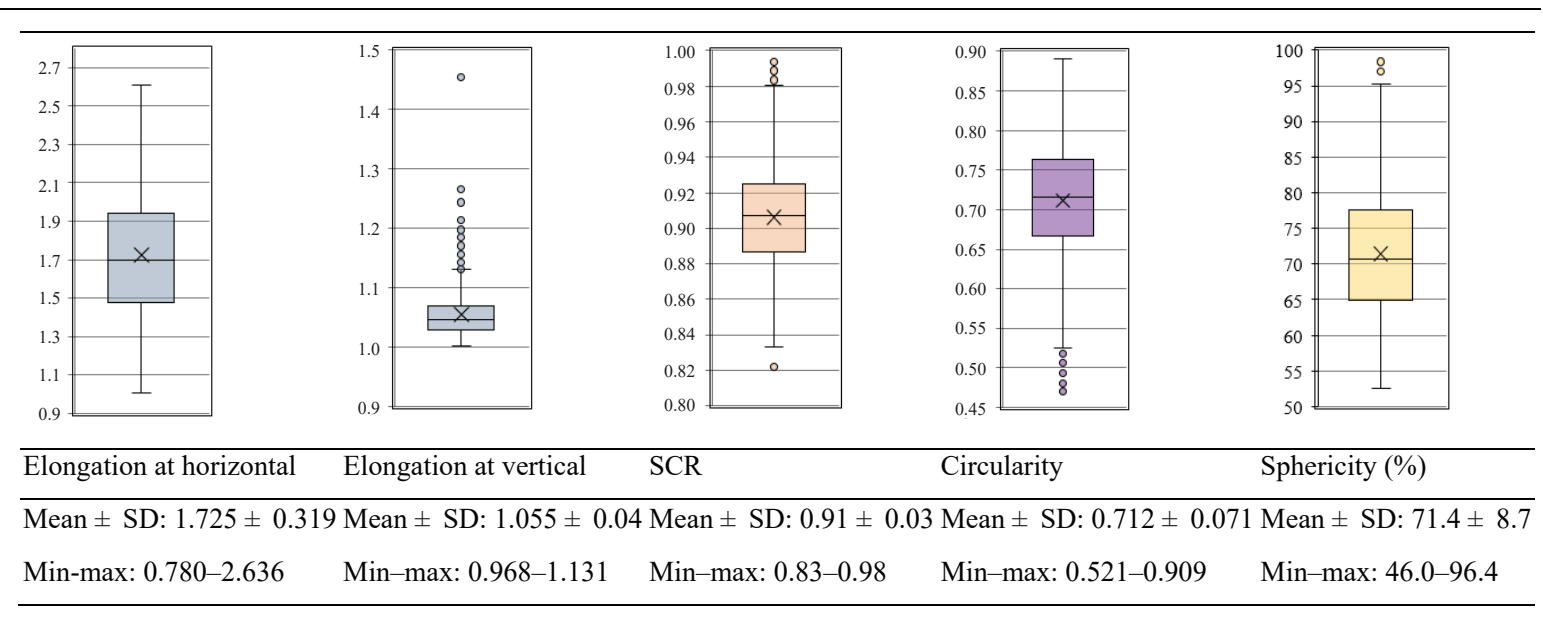

Figure 3. Shape and size characteristics of rosehip genotypes. SD, standard deviation of a sample; SCR, surface closure rate.

Table 2. Eigen statistics and vectors for three PCs.

\begin{tabular}{lcrr}
\hline Physical attributes & PC1 & PC2 & PC3 \\
\hline Surface area & 0.997 & & \\
Geometric mean diameter & 0.997 & & \\
Volume & 0.997 & & \\
Elongation at horizontal & & -0.989 & \\
Sphericity & & 0.979 & \\
Circularity & & 0.952 & \\
SCR & & & 0.998 \\
\hline Eigenvalues & 3.000 & 2.860 & 1.041 \\
\% of variance & 42.853 & 40.853 & 14.865 \\
Cumulative (\%) & 42.853 & 83.706 & 98.571 \\
\hline
\end{tabular}

PC, principal component; SCR, surface closure rate.

\section{Shape variations identified with $E F A$}

The first three PCs identified based on shape contour codes explained $91.56 \%$ of the total variation in shapes of rosehip genotypes (Figure 5). The average shape contour looks like an ellipse. PC1 explained the greatest portion of total variation (82.65\%). However, when the \pm 2 standard deviation of a sample (SD) range was evaluated, it was seen that genotypes had different geometries from each other as of thin/long and sphere. There is a large variation in the transverse shape change (contraction and expansion). PC2 explained $6.38 \%$ of the total variation. This variation explained tapering and flattening at the fruit base. PC 3 explained $2.53 \%$ of the total variation. This component indicated that there was 


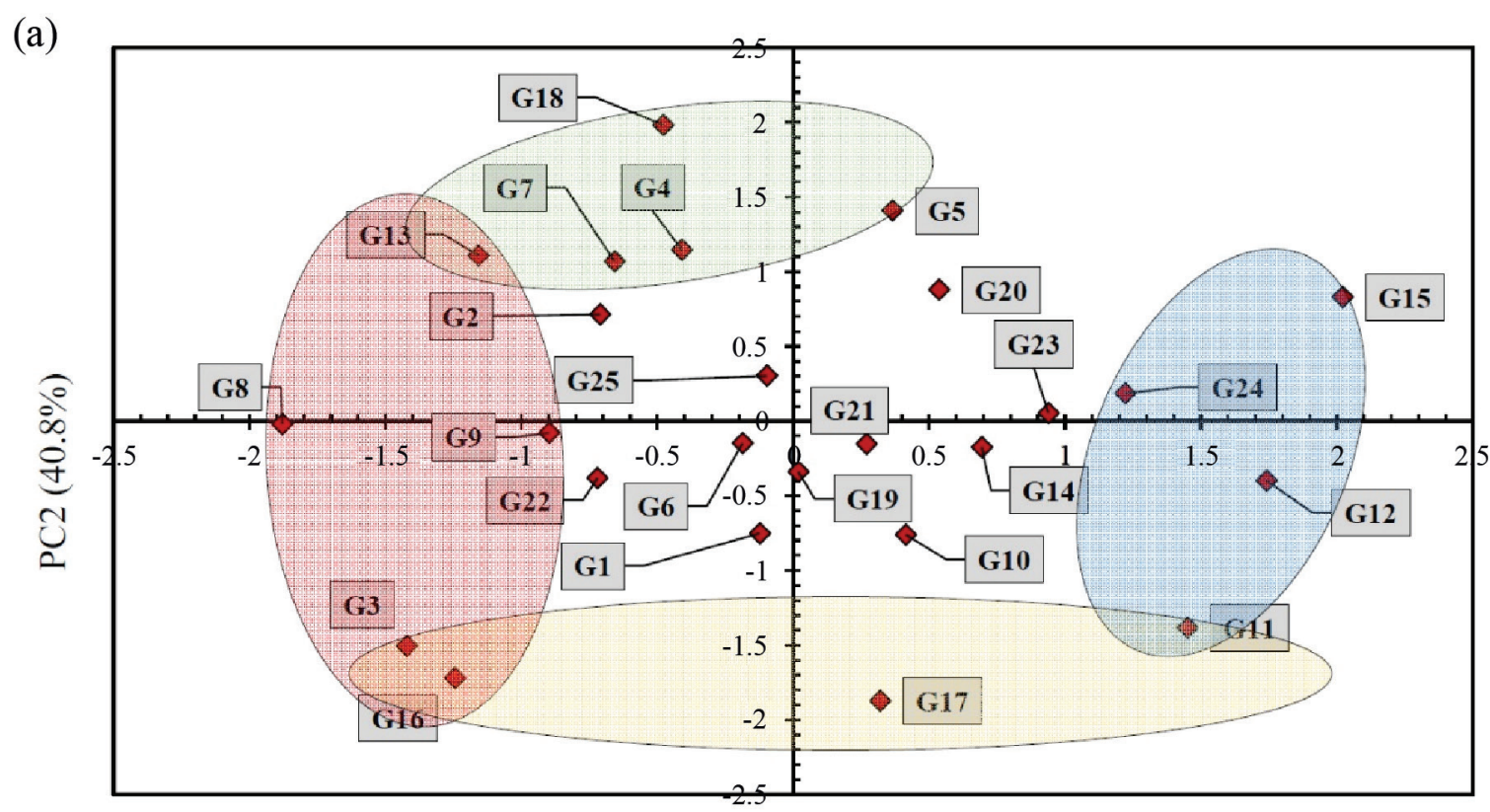

PC1 $(42.8 \%)$

(b)

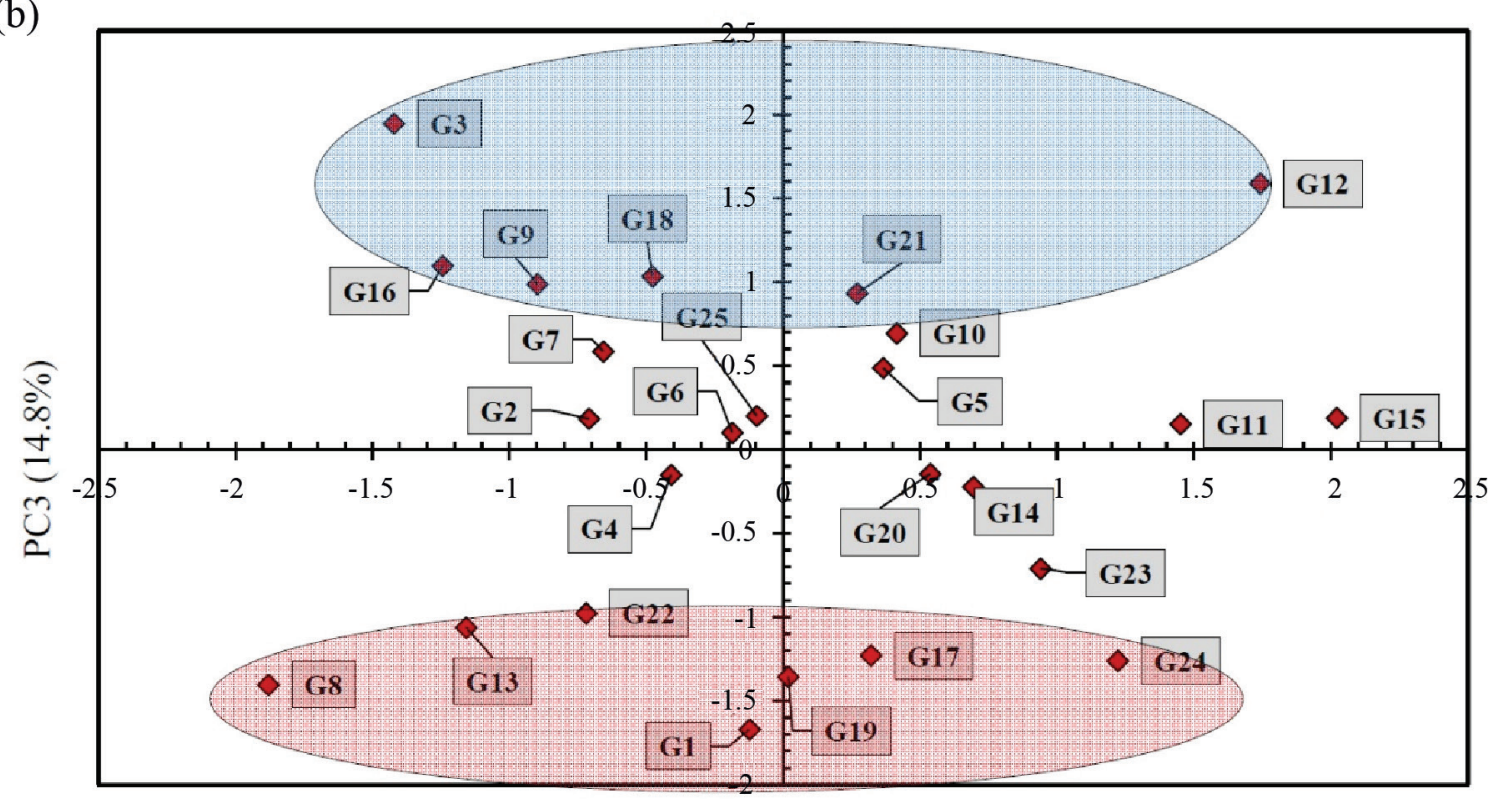

PCl $(42.8 \%)$

Figure 4. PC analysis scatter plot made on shape and size data. (A) Distribution of genotypes according to PC1 and PC2. (B) Distribution of genotypes according to PC1 and PC3. PC, principal component.

an asymmetric shape change between the genotypes on the horizontal plane. The genotypes constituting this variation had a stoop appearance. These findings play a great role in identification of opening shapes in classification and separation systems (Demir et al., 2020).

\section{Linear discriminant analysis results}

The first three functions identified with linear discriminant analysis were able to discriminate
$96.7 \%$ of shape variations between the genotypes (Table 3a). The first function had the greatest ratio of discrimination $(81.8 \%)$. The second and third functions had discrimination ratios of $10.6 \%$ and $4.3 \%$ for shape differences, respectively. According to Table $3 \mathrm{~b}$ presenting the MANOVA results, shape differences between rosehip genotypes were highly significant $(p<0.001)$. The pairwise shape differences were analysed with paired Hotelling's test and the results are provided in Table $3 \mathrm{c}$. 


$22.65 \%$ of total variance

Figure 5. Change in shape contours of genotypes according to PC scores determined by EFA (from left to right: mean $-2 \mathrm{SD}$, mean, mean $+2 \mathrm{SD}$ ). EFA, elliptic Fourier analysis; PC, principal component.

The verified Bonferroni results given in the bottom triangle revealed that almost all of the genotype pairs had highly significant shape differences. In this test, the shape differences only between G6 and G9-G14 genotypes and G14-G19 genotypes were not found to be significant. The similarities and differences in genotypes pairs could more clearly be seen through the Mahalonabis distances provided in the top triangle of Hotelling's test. Similarity increases as the Mahalonabis distance approaches to 0. It could clearly be seen in terms of the shape that genotype G18 was different from the others.

Figure $6 \mathrm{~A}$ and $6 \mathrm{~B}$ presents the scatter plot for discriminant functions, genotypes G13 and G18 were placed on right side of Function 1 axis and the outermost position. It is remarkable that these genotypes had a spherical shape. The genotype G17 was placed on the left side of Function 1 axis and the furthest position, but still beneath the Function 3 axis. In terms of shape, this genotype had an asymmetric appearance on the longitudinal plane. Although G22 genotype was close to the centroid of Functions 1 and 2, it was far from Function 3. This genotype had an ellipse shape.

\section{Hierarchical cluster analysis results}

The shape similarities and differences presented in the scatter plots were proved with hierarchical cluster analysis. As can be seen in Figure 7, the dendrogram had two main groups (I and II). Both groups had three subgroups. The closest genotypes were identified as G14 and G19. This finding complies with the paired comparison tests and scatter plots. In previous studies, clustering analysis was conducted in walnuts (Demir et al., 2018) and cherry laurel (Sayinc1 et al., 2015a) and shape differences were successfully put forth.

\section{CONCLUSION}

The present rosehip ( $R$. canina) genotypes collected from the natural flora of two different provinces were found to be rich in bioactive compounds. The present analysis revealed that genotypes G19 and G20 were prominent for biochemical traits. The antioxidant activity $\left(39.510-72.673 \mathrm{mmol} \cdot \mathrm{kg}^{-1}\right)$, total flavonoids (287.80-1,686.20 $\mathrm{mg}$ QE $\cdot \mathrm{kg}^{-1}$ ) and total phenolics $\left(38,519.40-79,080.60 \mathrm{mg} \mathrm{GAE} \cdot \mathrm{kg}^{-1}\right)$ of the genotypes exhibited large variations. The present findings revealed that sampling provinces influenced the bioactive substances of the genotypes. Differences from the findings of previous studies were mostly resulted from differences in genotypes, altitude, soil and climate conditions, ecological conditions, fruit ripening levels and extraction methods.

The rosehip genotypes had greater length values than the width and thickness values. The geometric shape of the genotypes at vertical orientation was circular. At horizontal orientation, the average length/width ratio was 1.7, thus the geometric shape was an ellipse. Based on the dimensional measurements made on three axes, the average sphericity of the genotypes was calculated as $71.4 \%$. Although it was concluded based on the general average that genotypes did not resemble a sphere, the min-max ranges revealed that there were genotypes with a close form to a sphere. G18 was the closest genotype to a sphere. The most important dimensional traits discriminating genotypes from each other were identified as the surface area, geometric mean diameter and volume. While G15 genotype had the greatest dimensional traits, G8 genotype had the lowest values. The primary geometric shape of the genotypes looks like a sphere. There were shape differences between the genotypes like long, circular, flat bottom, pointed 


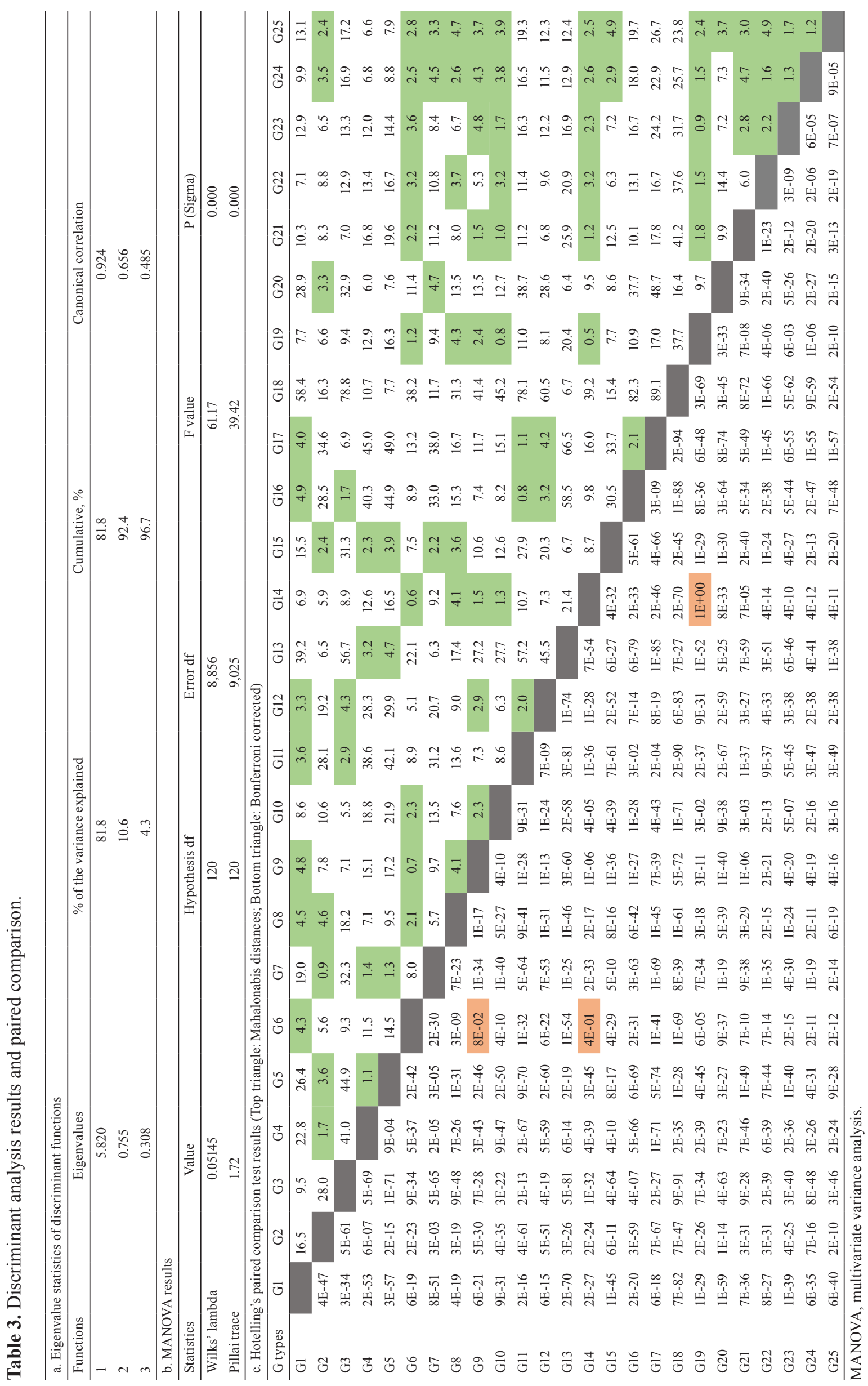


a)

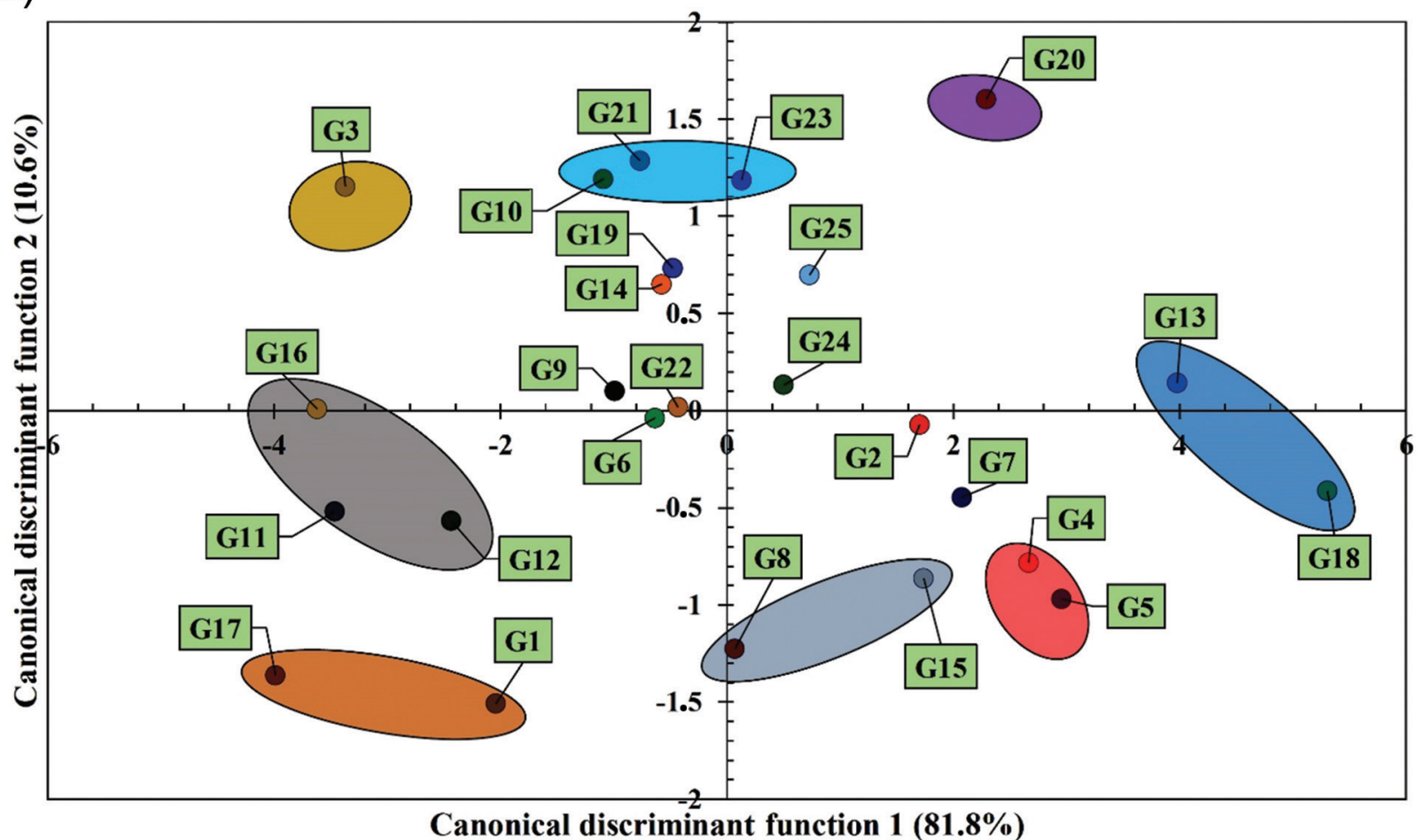

b)

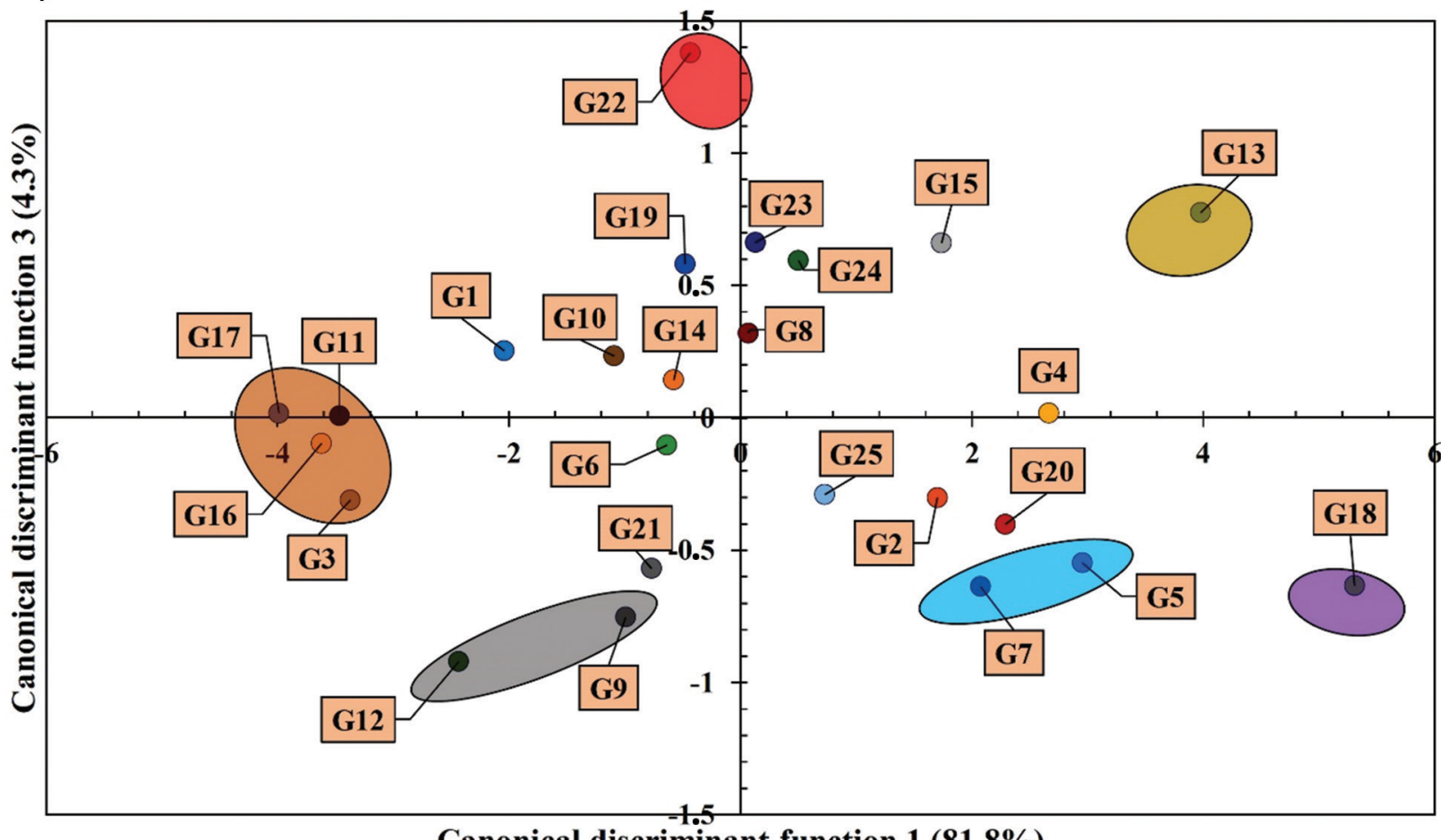

Canonical discriminant function $1(81.8 \%)$

Figure 6. Centripetal distribution of canonical separation functions explaining the shape variations of rosehip genotypes. (A) Functions 1 and 2. (B) Functions 1 and 3.

bottom and asymmetric. The shape differences of 25 rosehip genotypes were successfully put forth with linear discriminant analysis, paired comparison test and hierarchical cluster analysis. In terms of shape traits, genotypes were classified into six main groups. Group
I included only G18; Group II included G2, G15 and G20; Group III included G4, G5, G7 and G13; Group IV included only G1 and G12; Group V included G6, G8, G9, G10, G14, G19, G21, G22, G23, G24 and G25 and Group VI included G3, G11, G16 and G17 genotypes. 


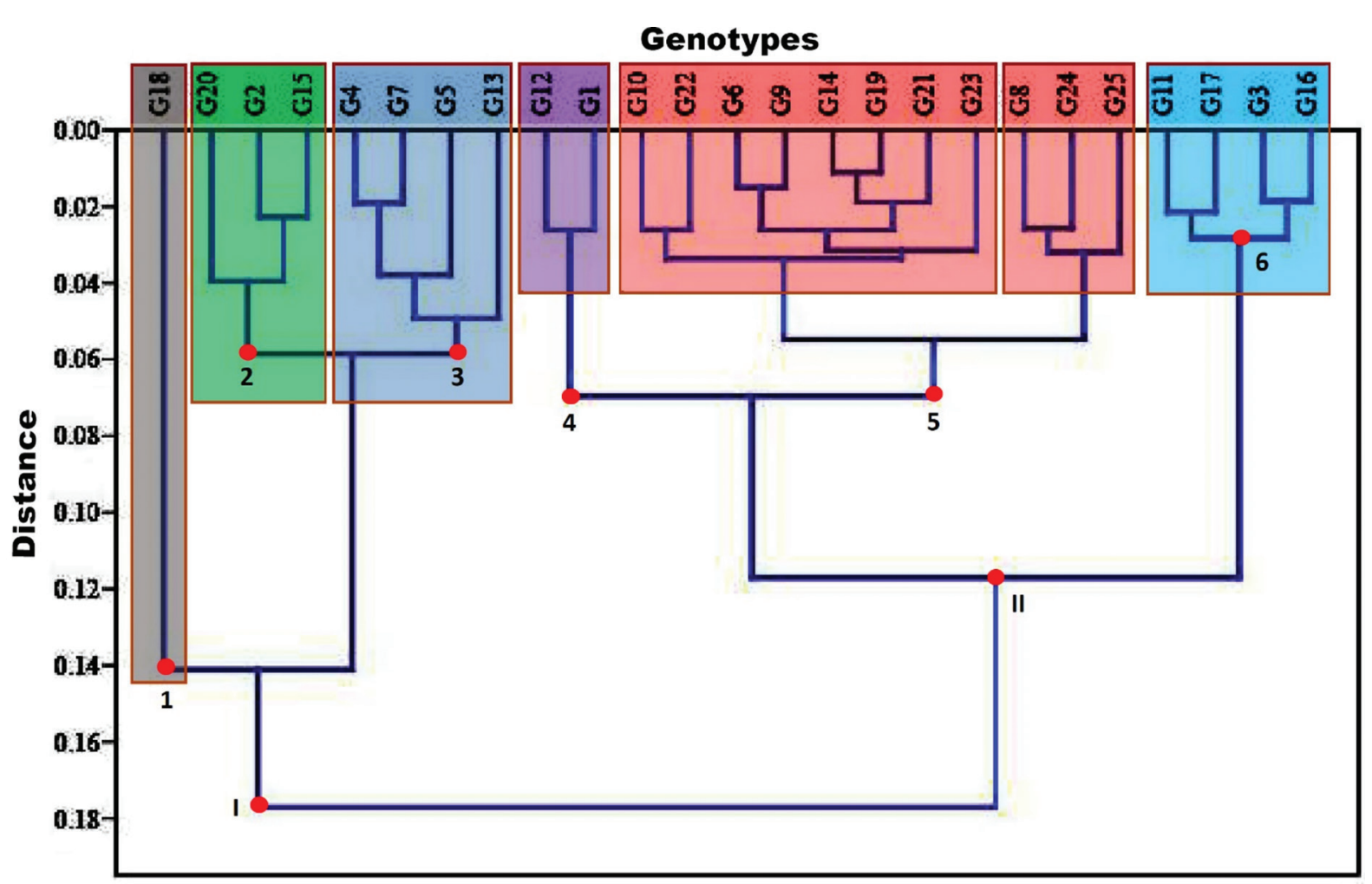

Figure 7. Hierarchical clustering analysis of the first five PC scores determined by EFA (Paired (UPGMA) algorithm and Euclidean similarity index). EFA, elliptic Fourier analysis; PC, principal component.

\section{FUNDING}

This research was not funded.

\section{AUTHOR CONTRIBUTIONS}

All the authors contributed equally to all aspects of the manuscript.

\section{CONFLICT OF INTEREST}

Authors declare no conflicts of interest.

\section{REFERENCES}

Adamczak, A., Buchwald, W., Zieliński, J., AND MielcareK, S. (2012). Flavonoid and organic acid content in rose hips (Rosa L., sect. Caninae DC. EM. Christ.). Acta Biologica Cracoviensia Series Botanica, 54(1), 105-112.

Alp, S., Ercisli, S., Dogan, H., Temim, E., Leto, A., Zia-Ul-Haq, M., Hadziabulic, A., and Aladag, H. (2016). Chemical composition and antioxidant activity Ziziphora clinopodioides ecotypes from Turkey. Romanian Biotechnological Letters, 21(2), 11298-11303.

Anon. (2020). Devlet Meteoroloji Işsleri Genel Müdürlüğ̈̈ Kayıtları. Ankara, Turkey.

Aptin, R., Ghavamaldin, A., Ahmad, T., AND Mariamalsadat, T. (2013). Evaluation of biochemical compounds Rosa canina L. in North of
Iran (Ramsar and Tonekabon Heights). Journal of Medicinal Plants Research, 7(45), 3319-3324.

Bart-Plange, A., Dzisi K. A., and Ampah, J. (2012). Effect of drying on selected physical properties of "Asontem" cowpea variety. International Scholarly Research Notices, 2012, 496026, doi: 10.5402/2012/496026.

Beyhan, O., Elmastas, M., and Gedikli, F. (2010). Total phenolic compounds and antioxidant capacity of leaf. dry fruit and fresh fruit of feijoa (Acca sellowiana, Myrtaceae). Journal of Medicinal Plants Resarch, 4, 1065-1072.

Beyhan, O., Koc, A., Ercisli, S., Jurikova, T., And CAKIR, O. (2017). Bioactive content of Rosa canina biotypes from Turkey. Oxidation Communications, 40, 178-185.

Brand-Williams, W., Cuvelier, M. E., and Berset, C. L. W. T. (1995). Use of a free radical method to evaluate antioxidant activity. $L W T-$ Food Science and Technology, 28, 25-30.

Chang, C. C., Yang, M. H., Wen, H. M., and Chern, J. C. (2002). Estimation of total flavonoid content in propolis by two complementary colorimetric methods. Journal of Food and Drug Analysis, 10, 13-21.

Deliorman, O. D., Hartevioglu, A., Kupeli, E., And YesiladA, E. (2007). In vivo anti-inflammatory and antinociceptive activity of the crude extract and fractions from Rosa canina L. fruits. Journal of Ethnopharmacology, 112, 394-400. 
Demir, B., Sayinci, B., Çetin, N., Yaman, M., And ÇömLEK, R. (2019). Shape discrimination of almond cultivars by elliptic Fourier descriptors. ErwerbsObstbau, 61(3), 245-256.

Demir, B., Sayinci, B., Çetin, N., Yaman, M., Çömlek, R., Aydin, Y., and Sütyemez, M. (2018). Elliptic Fourier based analysis and multivariate approaches for size and shape distinctions of walnut (Juglans regia L.) cultivars. Grasas y Aceites, 69(4), 1-12.

Demir, B., Sayinci, B., Sümbül, A., Yaman, M., Yildiz, E., Çetin, N., Karalaya, O., and Ercişli, S. (2020). Bioactive compounds and physical attributes of Cornus mas genotypes through multivariate approaches. Folia Horticulturae, 32(2), 189-202.

Demir, F., And Özcan, M. (2001). Chemical and technological properties of rose (Rosa canina L.) fruits grown wild in Turkey. Journal of Food Engineering, 47, 333-336.

Demir, N., Yildiz, O., Alpaslan, M., and Hayaloglu, A. A. (2014). Evaluation of volatiles, phenolic compounds and antioxidant activities of rose hip (Rosa L.) fruits in Turkey. LWT - Food Science and Technology, 57(1), 126-133.

Dogan, H., Ercisli, S., Jurikova, T., Temim, E., Leto, A., Hadziabulic, A., Tosun, M., Narmanlioglu, H. K., And ZiA-Ul-HaQ, M. (2014). Physicochemical and antioxidant characteristics of fruits of cape gooseberry (Physalis peruviana L.) from Turkey. Oxidation Communications, 37, 1005-1014.

Engin, S. P., And Mert, C. (2020). The effects of harvesting time on the physicochemical components of aronia berry. Turkish Journal of Agriculture and Forestry, 44, 361-370.

ERCISLI, S. (2005). Rose (Rosa spp.) germplasm resources of Turkey. Genetic Resources and Crop Evaluation, 52, 787-795.

ERcisli, S. (2007). Chemical composition of fruits in some rose (Rosa spp.) species. Food Chemistry, 104, 1379-1384.

Ercisli, S., SAyinci, B., Kara, M., Yildiz, C., And Ozturk, I. (2012). Determination of size and shape attributes of walnut (Juglans regia L.) genotypes using image processing. Scientia Horticulturae, 133, 47-55.

Eroglu, D., And Oguz, H. I. (2018). Determining the physico-chemical characteristics of the rosehip genotypes grown naturally in Adiyaman province. Erwerbs-Obstbau, 60(3), 195-201.

Fattahi, S., Jamei, R., and SArghein, S. H. (2012). Antioxidant and antiradical activities of Rosa canina and Rosa pimpinellifolia fruits from West Azerbaijan. Iranian Journal of Plant Physiology, 2, 523-529.

Fooddata Central. (2019). Retrieved from https://fdc. nal.usda.gov/fdc-app.html\#/food-details/171722/ nutrients. [Accessed 05/10/2020].

Gecer, M. K., Kan, T., Gundogdu, M., Ercisli, S., Ilhan, G., And Sagbas, H. I. (2020). Physicochemical characteristics of wild and cultivated apricots (Prunus armeniaca L.) from Aras valley in Turkey. Genetic Resources and Crop Evolution, 67, 935-945.

Gundogdu, M., Ozrenk, K., Ercisli, S., Kan, T., Kodad, O., And Hegedus, A. (2014). Organic acids, sugars, vitamin $\mathrm{C}$ content and some pomological characteristics of eleven hawthorn species (Crataegus spp.) from Turkey. Biological Research, 47(1), 21, doi: 10.1186/0717-6287-47-21.

Hornero-Mendez, D., And Minquez-Mosquera, M. I. (2000). Carotenoid pigments in Rosa mosqueta hips an alternative carotenoide source for foods. Journal of Agricultural and Food Chemistry, 48, 825-828.

Hvattum, E. (2002). Determination of phenolic compounds in rose hip (Rosa canina) using liquid chromatography coupled to electrospray ionisation tandem mass spectrometry and diyodearray detection. Rapid Communications in Mass Spectrometry, 16, 655-662.

Ilisulu, K. (1992). Drug and spice plant. Ankara: Ankara University Agriculture Faculty Publication, $302 \mathrm{p}$.

IwATA, H., AND UKAI, Y. (2002). SHAPE: A computer program package for quantitative evaluation of biological shapes based on elliptic Fourier descriptors. Journal of Heredity, 93, 384-385.

Kaskoniene, V., Bimbiraite-Surviliene, K., Kaskonas, P., Tiso, N., Cesoniene, L., Daubaras, R., and Maruska, A. S. (2020). Changes in the biochemical compounds of Vaccinium myrtillus, Vaccinium vitisidaea, and forest litter collected from various forest types. Turkish Journal of Agriculture and Forestry, 44, 557-566.

Kasun, S. (2017). Determination of total phenolic content, phenolic composition, antioxidant capacities and some physicochemical features of rosehip (Rosa canina) and hawthorn (Crataegus orientalis) wild fruits growing in the region of Tunceli. Master Thesis, Munzur University, Tunceli, $102 \mathrm{p}$.

Kostic, S. (1994). Nutritive value of rose hips and its usability in baby food vitaminization. Review of Research Work at the Faculty of Agriculture, 39(1), 67-71.

Kutbay, H. G, and Kilinc, M. (1996). Taxonomic properties of rose hip species are grown in Turkey. Paper presented at the $1^{\text {st }}$ National Rose hip Conference, Gümüşhane, Turkey, 75-83.

Layina-Pathirana, C. M., Shahidi, F., and Alasalvar, C. (2006). Antioxidant activity of cherry laurel fruit (Laurocerasus officinalis Roem.) and its concentrated juice. Food Chemistry, 99, $121-128$.

Mohsenin, N. N. (1986). Physical properties of plant and animal materials. New York, USA: Gordon and Breach Science Publishers.

Montazeri, N., Baher, R., Mirzajani, F., Barami, Z., And Youseian, S. (2011). Phytochemical contents 
and biological activities of Rosa canina fruit from Iran. Journal of Medicinal Plant Research, 5(18), 4584-4589.

Murathan, Z. T, Zarifikhosroshahi, M., KafKas, E., And Sevindik, E. (2016). Characterization of bioactive compounds in rosehip species from East Anatolia Region of Turkey. Italian Journal of Food Science, 28, 314-325.

Nadpal, J. D., Lesjak, M. M., Šibul, F. S., Anackov, G. T., Cetojevic-Simin, D. D., Neda, M., Mimica-Dukic, N. M., AND BEARA, I. N. (2016). Comparative study of biological activities and phytochemical composition of two rose hips and their preserves: Rosa canina L. and Rosa arvensis Huds. Food Chemistry, 192, 907-914.

Nakamura, Y., Watanabe, S., Miyake, N., Kohno, H., AND OsAWA, T. (2003). Dihydrochalcones: Evaluation as novel radical scavenging antioxidants. Journal Agriculture Food Chemistry, 51, 3309-3312.

Neto, J. C., Meyer, G. E., Jones, D. D., and Samal, A. K. (2006). Plant species identification using Elliptic Fourier leaf shape analysis. Computers and Electronics in Agriculture, 50, 121-134.

NiLson, O. (1972). Flora of Turkey and the East Aegean Islands. In P. H. Davis (Ed.), pp. (pp. 106-128). Edinburgh, UK: University Press.

Ninomiya, K., Matsuda, H., Kubo, M., Morikawa, T., Nishida, N., and Yoshikawa, M. (2007). Potent anti-obese principle from Rosa canina: Structural requirements and mode of action of transtiliroside. Bioorganic and Medicinal Chemestry Letters, 17, 3059-3064.

Olsson, M. E., Gustavsson, K. E., Andersson, S., Nilsson, A., AND DuAn, R. D. (2004). Inhibition of cancer cell proliferation in vitro by fruit and berry extracts and correlations with antioxidant levels. Journal of Agricultural and Food Chemistry, 52, 7264-7271.

Orhan, D. D., Ozluk, O., And Coskun, S. H. (2012). Antioxidant capacities, ascorbic acid and total phenol contents of the plants sold as rosehip in Turkey. FABAD Journal of Pharmaceutical Sciences, 37, 161-167.

Ozkan, G., Sagdic, O., Baydar, N. G., and Baydar H. (2004). Note: Antioxidant and antibacterial activities of Rosa damascene flower extracts. Food Science and Technology International, 10, 277-281.

OzKan-KocA, A. (2012). Ortadoğu'da yayılış gösteren Apis mellifera L. (Hymenoptera: Apidae) alttürlerinin geometrik morfometri yöntemiyle analizi. Ankara Üniversitesi Fen Bilimleri Enstitüsü, Biyoloji Anabilim Dalı (Doktora Tezi), Ankara, 167 s. (in Turkish).

Ozturk, I., Ercisli, S., Kalkan, F., and Demir, B. (2009). Some chemical and physico-mechanical properties of pear cultivars. African Journal of Biotechnology, 8(4), 687-693.

Paunovic, D., Kalusevic, A., Petrovic, T., Urosevic, T., Disnovic, D., Nedovic, V., And Popovic-Djordjevic,
J. (2019). Assessment of chemical and antioxidant properties of fresh and dried rosehip (Rosa canina L.). Notulae Botanicae Horti Agrobotanici, 47(1), 108-113.

Pieroni, A., And Quave, C. L. (2005). Traditional pharmacopoeias and medicines among Albanians and Italians in southern Italy: A comparison. Journal of Ethnopharmacology, 101(1-3), 258-270.

Roman, I., Stănilă, A., And StĂnilă, S. (2013). Bioactive compounds and antioxidant activity of Rosa canina L. biotypes from spontaneous flora of Transylvania. Chemical Central Journal, 7(1), 73-82.

SAYINCI, B, (2016). Poliasetal (POM) meme plakalarının orifis geometrisinde üretim kusurlarının eliptik fourier tanımlayıcılarıyla tespiti. Uludağ Üniversitesi Ziraat Fakültesi Dergisi, 30(1), 57-73.

SAyinci, B., Ercișli, S., Akbulut, M., Şavşatli, Y., And BAYKAL, H. (2015a). Determination of shape in fruits of cherry laurel (Prunus laurocerasus) accessions by using Elliptic Fourier analysis. Acta Scientiarum Polonorum, Hortorum Cultus, 14(1), 63-82.

SAYinci, B., Kara, M., ERcișli, S., DuYar, Ö., AND ERTÜRK, Y. (2015b). Elliptic Fourier analysis for shape distinction of Turkish hazelnut cultivars. Erwerbs-Obstbau, 57(1), 1-11.

Serce, S., Ozgen, M., Torun, A. A., And Ercisli, S. (2010). Chemical composition, antioxidant activities and total phenolic content of Arbutus andrachne L. (Fam. Ericaceae) (the Greek strawberry tree) fruits from Turkey. Journal of Food Composition and Analysis, 23(6), 619-623.

Soare, R., Babeanu, C., Bonea, D., and Panita, O. (2015). The content of total phenols, flavonoids and antioxidant activity in rosehip from the spontaneous flora from south Romania. Scientific Papers-Series A, Agronomy, 58, 307-314.

Su, L., Yin, J.-J., Charles, D. C., Zhou, K., Moore, J., And YU, U. L. (2007). Total phenolic contents, chelating capacities, and radical-scavenging properties of black peppercorn, nutmeg, rose hip, cinnamon and oregano leaf. Food Chemistry, 100, 990-997.

Szentminalyi, K., Vinkler, P., Lakatos, B., Illes, V., And Then, M. (2002). Rose hip (Rosa canina L.) oil obtained from waste hip seeds by different extractions methods. Bioresource Technology, 82, 195-201.

Taneva, I., Petkova, N., Dimov, I., Ivanov, I., and Denev, P. (2016). Characterization of rose hip (Rosa canina L.) fruits extracts and evaluation of their in vitro antioxidant activity. Journal of Pharmacognosy and Phytochemistry, 5(2), 35-38.

Tapiero, H., Tew, K. D., BA, G. N., and Mathe, G. (2002). Polyphenols: Do they play a role in the prevention of human pathologies. Biomedicine and Pharmacotheraphy, 56, 200-207.

TAstekin, B. (2017). An investigation of antioxidant capacity and antibacterial potential of rosehip fruits grown in Samsun and surroundings. Master Thesis, Ondokuz Mayıs University, Samsun, 66 p. 
Tumbas, V. T., Čanadanović-Brunet, J. M., Gille, L., Đilas, S. M., And ĆEtKović, G. S. (2012). Characterization of the free radical scavenging activity of rose hip (Rosa canina L.) extract. International Journal of Food Properties, 15(1), 188-201.

UgGla, M., Gustavsson, K. E., Olsson, M. E, and Nybom, H. (2005). Changes in colour and sugar content in rose hips (Rosa dumalis L. and Rosa rubiginosa L.) during ripening. Journal of Horticultural Sciences and Biotechnology, 80(2), 204-208.

Wu, X., Gu, L., Holden, J., Haytowitz, B. D., Gebhardt, E. S., Beecher, G., And Prior, R. L. (2004). Development of a database for total antioxidant capacity in foods: A preliminary study. Journal of Agricultural and Food Chemistry, 17, 407-422.

Yildiz, O., AND Alpaslan, M. (2012). Properties of rose hip marmalades. Food Technology and Biotechnology, 50(1), 98-106.

Yilmaz, S. O., AND ERcisli, S. (2011). Antibacterial and antioxidant activity of fruits of some rose species from Turkey. Romanian Biotechnological Letters, 16(4), 6407-6411.

Yolcu, H. (2010). Changes of antioxidant properties in rosehip pulp production. Master Thesis, Ondokuz Mayıs University, Samsun, 64 p.

Received: May 24, 2021; accepted July 24, 2021 